\title{
Proangiogenic activity of plant extracts in accelerating wound healing - a new face of old phytomedicines
}

\author{
Iwona Majewska and Edyta Gendaszewska-Darmach ${ }^{\bowtie}$ \\ Institute of Technical Biochemistry, Faculty of Biotechnology and Food Sciences, Technical University of Łódź, Łódź, Poland
}

\begin{abstract}
Angiogenesis, the formation of new capillaries from pre-existing vascular network, plays an important role in physiological and pathological processes such as embryonic development, wound healing, and development of atherosclerosis. Extension of the circulatory network is also considered to be one the most important factors during cancerogenesis. Inhibition of angiogenesis may lead to inhibition of tumor growth whereas stimulation may improve wound healing. Research achievements suggest the use of plants and their extracts as potential therapeutic agents with pro- or antiangiogenic activity. Since the anticancer and antiangiogenic properties of many phytomedicines have been amply reviewed elsewhere this paper will focus on the treatment of vascular insufficiency in wound healing. Globally accepted herbal drugs are thought to be safe and effective, however, there is a need for more evidence-based confirmation in controlled and validated trials. Among the most frequently studied proangiogenic phytochemicals are ginsenosides from Panax ginseng, beta-sitosterol from Aloe vera, calycosin from Radix Astragali, and extracts from Hippophae rhamnoides L. and Angelica sinensis.
\end{abstract}

Keywords: wound healing, angiogenesis, phytomedicines, plant extracts

Received: 19 May, 2011; revised: 29 August, 2011; accepted: 15 September, 2011; available on-line: 27 October, 2011

\section{INTRODUCTION}

Wounds have affected humans since prehistoric times and the treatment and healing of wounds is an art as old as humanity (Robson et al., 2001). Due to the increasing life expectancy coupled with a more modern way of life, wounds and particularly chronic wounds increasingly affect a growing number of elderly patients and seriously reduce their quality of life. Current estimates indicate that nearly 6 million people suffer from chronic wounds (Kumar et al., 2007) causing great physiological and mental trauma. In the United States, chronic wounds cost the nation $\$ 20$ billion to $\$ 25$ billion a year, and acute or traumatic wounds add another $\$ 7$ billion to $\$ 10$ billion annually. Research on wound healing drugs is a rapidly developing area of modern biomedical sciences. The progress in this field has allowed the synthesis of large numbers of molecules associated with wound repair process. Delivery of exogenous growth factors in order to mimic the natural microenvironments of tissue formation and repair is believed to be therapeutically effective. The most important among the growth factors are recombinant human platelet-derived growth factor-BB and granulocyte colony-stimulating factor. The former has been approved by the U.S. Food and Drug Administration (FDA) for the treatment of neuropathic ulcers when there is adequate blood supply. However, recent analysis shows that their clinical efficacy is limited ( $\mathrm{Pa}-$ panas \& Maltezos; 2007). Despite finding new methods of stimulation of the wound repair process, wound care has returned to the roots of medicine and is embracing some of the remedies used millennia ago. Plant-derived natural products are significant as sources of medicinal agents and models for the design of new remedies. Such pharmaceuticals as morphine isolated from the opium poppy, salicylic acid from the bark of the willow tree or ephedrine from the Chinese herb mahuang are but a few examples of the many medicinally important substances (Fan et al., 2006). Nowadays plant-derived compounds play an important role in drug development as exemplified by taxol and camptothecin (anticancer agents), artemisinin (the Chinese antimalarial drug), and forskolin (the East Indian Ayurvedic drug) (Balandrin et al., 1993).

As plants are a source of many bioactive compounds and many plant ingredients are traditionally used to accelerate healing, scientists go back to traditional folk medicines as they are generally characterized by high acceptability and good toleration (Jagetia et al., 2004).

The healing potential of phytomedicines is often associated with angiogenesis, which is a critical step of wound healing. It is the essential part of the repair process as it enables the nutrient supply to sustain cell metabolism, creates an intact delivery system, and facilitates the clearance of debris. Approximately $60 \%$ of the granulation tissue mass is composed of blood vessels which also supply the necessary oxygen to stimulate repair and vessel growth. Impaired wound healing may be a consequence of pathologic states associated with diabetes, im-

\section{e-mail: edarmach@wp.pl}

Abbreviations: aFGF or FGF-1, acidic fibroblast growth factor; bFGF or FGF-2, basic fibroblast growth factor; CAM, chorioallantoic membrane; ECM, extracellular matrix; EGF, epidermal growth factor; eNOS, endothelial nitric oxide synthase; ER, estrogen receptor; ERK1/2, extracellular-signal-regulated kinases; FAK, focal adhesion kinase; FDA, food and drug administration; FGFR, fibroblast growth factor receptor; GR, glucocorticoid receptor; HIF-1, hypoxiainducible factor 1; HUVEC, human umbilical vein endothelial cells; IGF, insulin-like growth factor; IGFR, insulin growth factor receptor; JNK, c-Jun N-terminal kinases; MAPKs, mitogen-activated protein kinases; MMPs, matrix metalloproteinases; PDGF, platelet-derived growth factor; PHF, poly-herbal formulation; PI3K, phosphatidylinositol 3-kinases; PKB, protein kinase $B$; ROS, reactive oxygen species; RTK, receptor tyrosine kinase; SBT, seabuckthorn; TGF-a transforming growth factor alfa; TGF- $\beta$, transforming growth factor beta; u-PA, urokinase-type plasminogen activator; VE-cadherin, vascular endothelial cadherin; VEGF, vascular endothelial growth factor; VEGFR-1, vascular endothelial growth factor receptor type1 (Flt, Fms-like tyrosine kinase); VEGFR-2, vascular endothelial growth factor receptor type-2 (KDR/FIk-1; kinase-domain region/ fetal liver kinase-1); vWF, von Willebrand factor. 
mune disorders, ischemia, venous stasis, and in injuries such as burn, frostbite, and gunshot wounds. Patients with venous insufficiency associated for example with diabetes develop deep ulceration/wounds on the lower limbs (Pettet et al., 1996). Proangiogenic factors present in wound fluid promote repair while antiangiogenic factors inhibit it. The healing efficacy seen in phytomedicine-treated wounds shows great promise although for most natural products no well-controlled scientific data are available.

\section{WOUND HEALING AND ANGIOGENESIS}

The Wound Healing Society defines wound healing as a "complex dynamic process that results in the restoration of anatomic continuity and function" (Strodtbeck, 2001). It involves interactions of extracellular matrix molecules, soluble mediators and various cells that cooperate to repair the injury. It also requires coordination of overlapping distinct cellular activities, involving phagocytosis, chemotaxis, mitogenesis, angiogenesis, and synthesis of collagen and other matrix components (Gurtner et al., 2008). Wound repair is divided into four phases that overlap in time and space: haemostasis, inflammation, tissue formation (proliferative phase), and tissue remodeling. All these phases have specific contributions to blood vessel growth and remodeling (Schultz, 2007).

The haemostasis phase starts immediately after injury to prevent exsanguination and supply a matrix for invading cells. Within 24 hours platelets start to aggregate by binding to collagen that becomes exposed following rupture of the endothelial lining of vessels. The forming fibrin clot limits active bleeding and serves as a scaffolding for the recruitment of cells to the injured site. Additionally, it serves as a reservoir of the variety of growth factors and cytokines that are released as activated platelets degranulate. Insulin-like and epidermal growth factors (IGF, EGF), fibronectin, fibrinogen, histamine, platelet-derived growth factor (PDGF), serotonin and von Willebrand factor (vWF) act to control bleeding and limit the extent of injury. These molecules are also promoters of the wound healing cascade by activation and attraction of neutrophils, macrophages, endothelial cells and fibroblasts.

The inflammatory phase is characterized by influx of polymorphonuclear leukocytes (neutrophils). They are attracted to the wound within $24-36$ h of injury by chemoattractive agents, like transforming growth factor beta (TGF- $\beta$ ). Neutrophils gathered in the wound environment phagocytose foreign material and bacteria as well as they are also a source of pro-inflammatory cytokines which may also serve as the earliest signals that activate local fibroblasts and keratinocytes. Subsequently macrophages, attracted by clotting factors, complement components, PDGF, TGF- $\beta$, leukotriene $\mathrm{B}_{4}$, platelet factor $\mathrm{IV}$, and elastin and collagen breakdown products appear in the wound and continue the process of phagocytosis. Besides, macrophages activate keratinocytes, fibroblasts and endothelial cells by releasing TGF- $\beta$, TGF- $\alpha$, fibroblast growth factor (FGF), heparin-binding epidermal growth factors, and matrix metalloproteinases (MMPs). Macrophages also release PDGF and vascular endothelial growth factor (VEGF), which initiate the formation of granulation tissue and angiogenesis. Lymphocytes are the last cells entering the wound site during the late inflammatory phase (Strodtbeck, 2001; Velnar et al., 2009).

During the proliferative phase, a granulation tissue (new stroma) is formed. Fibroblasts constitute the pre- dominant cell type in granulation tissue. They start to proliferate and produce matrix components (hyaluronan, fibronectin, proteoglycans and type I and III procollagen), which are then deposited locally. Unwounded dermis contains about $80 \%$ type I collagen and 20\% type III collagen, while new granulation tissue contains $30 \%$ to $40 \%$ type III collagen, which does not contribute to restoring tensile strength in the wound (Robson et al., 2001). Fibroblasts change into their myofibroblast phenotype, which involves formation of pseudopodia capable of attaching to fibronectin and collagen in the extracellular matrix (ECM). This attachment starts the process of wound contraction leading to the approximation of the wound edges. In parallel to the formation of granulation tissue, increased proliferation and migration of keratinocytes takes place. During reepithelialization, basal keratinocytes undergo morphological changes required for their migration from the wound margin over the denuded area (Patel et al., 2005). Epidermal cells secrete MMPs that break down collagen, and plasminogen activator which stimulates the production of plasmin. When the migration is complete, keratinocytes are stabilized by formation of firm attachments to the new basement membrane. When the skin surface is completely covered with new epidermal cells, the wound is considered healed (Strodtbeck, 2001).

At the beginning of the injury, there is no vascular supply to the wound centre and some uninjured vessels perfuse only the marginal viable tissue. The wound clot is then invaded by capillary sprouts from the surrounding edges which leads to composition of a microvascular network within several days. Angiogenesis (or neovascularization) is an essential part of the repair process as it enables nutrient supply to sustain cell metabolism and create an intact delivery system. Angiogenesis initiates with the relaxation of cell contacts and disruption of the outer pericyte layer. Hence, endothelial cells become free to migrate and proliferate to form new vessels. In order to open space for the proliferating cells, local degradation of the basement membrane and extracellular matrix is induced (Robson et al., 2001). Angiogenesis is stimulated by growth factors and tissue hypoxia (Giordano \& Johnson, 2001). A hypoxic wound environment is created following the closure of the wound surface by fibrin clot. The hypoxic conditions are thought to induce macrophages to secrete angiogenetic factors such as basic fibroblast growth factor (bFGF or FGF-2) and acidic FGF (aFGF or FGF-1) that are released immediately after cell disruption (Gurtner et al., 2008). Also the production and release of PDGF and VEGF at the wound site is stimulated by hypoxia (Falanga, 2005). The shortage of oxygen causes an increase in the intracellular concentration of the active form of a gene regulatory protein called hypoxia-inducible factor 1 (HIF-1). HIF-1 binds to the hypoxia response element in the VEGF gene promoter region stimulating its transcription (Tsuzuki et al., 2000). VEGF up-regulation can be also caused by ischemia and several cytokines or growth factors including EGF, TGF- $\beta$, keratinocyte growth factor 1, and others (reviewed in Ferrara, 1999). However, VEGF is considered to be the predominant and the most effective angiogenic mediator in human cutaneous wounds (Khanna et al., 2001). VEGF acts by binding to two VEGF receptors, VEGFR-1 (Flt, Fms-like tyrosine kinase) and VEGFR-2 (KDR, kinase insert domain-containing receptor and its murine homolog, Flk-1). Activation of VEGFR-2 is connected with a mechanism dependent on the formation of a multi-protein complex that includes 
VEGFR-2, phosphatidylinositol 3-kinases (PI3K) and the adherens junction proteins VE-cadherin and $\beta$-catenin (Carmeliet et al., 2000). VEGF binding to cognate receptors on endothelial cells initiates autophosphorylation of VEGFR-2 that is followed by the activation of diverse angiogenesis-related enzymes such as mitogen-activated protein (MAP) and Akt/protein kinases B (PKB) to induce cell migration (Matsumoto \& Claesson-Welsh, 2001). Furthermore, VEGF influences endothelial cells through the PI3K-Akt-eNOS signaling cascade, which is responsible for various biological activities in angiogenesis (Chen et al., 2005). VEGF also induces angiogenesis by stimulating reactive oxygen species (ROS) production. ROS cause the oxidation of critical cysteine residues in protein tyrosine phosphatases such as SHP2 thereby deactivating them (Chiarugi \& Cirri, 2003). Besides, VEGF stimulates expression of urokinase-type activator, tissue-type plasminogen activator, plasmin, and matrix-degrading metalloproteinases capable of digesting basal lamina components (Hoeben et al., 2004; Stetler-Stevenson, 2008). Endothelial cells produce four matrix metalloproteinases, MMP-1, MMP-2, MMP-9, and MT-1-MMP secreted as zymogens. Degradation of the extracellular matrix by MMPs and other extracellular enzymes (heparinases and plasmin) releases growth factors bound to the ECM (e.g., VEGF, FGF, PDGF, TGF- $\beta$ ) (Park et al., 1993). Moreover, matrix metalloproteinases regulate VEGF bioavailability through intramolecular processing, and a subset of MMPs can cleave matrixbound isoforms of VEGF, releasing soluble fragments. The matrix-bound VEGF and free VEGF provide different signaling outcomes although, in the case of endothelial cells, they both act through VEGFR-2 (Lee et al., 2005).

VEGF is not the only growth factor inducing angiogenesis. Numerous growth factors such as angiopoietin-1/2, PDGF, FGF, and TGF- $\beta$ are involved in the control of various aspects of angiogenesis (Fig. 1). The first identified proangiogenic molecule was bFGF. FGFs are strong mitogens not only for fibroblasts but also for vascular endothelial cells and smooth muscle cells. The biological effects of FGFs are mediated by four structurally related receptor tyrosine kinases, FGFR-1, -2, -3, and
-4 (Cross \& Claesson-Welsh, 2001). Angiopoietin-1/2 induces cell migration by signaling through Tie 2 receptor whereas PDGF is required for vessel wall differentiation by recruiting pericytes to cover the outer surface of newly formed vessels. TGF- $\beta$ enhances synthesis of matrix metalloproteinases such as collagenases, gelatinases and stromelysins that are needed to degrade the underlying extracellular matrix (Krump-Konvalinkova et al., 2005). MMPs degrade collagen and other extracellular matrix elements, and through breaking down the basement membrane barrier, enable endothelial cells to migrate from pre-existing vessels towards angiogenic stimuli and to proliferate. The migration of endothelial cells is also facilitated by interactions between adhesion molecules, located on their surface (integrin $\alpha_{v} \beta_{3}, \alpha_{2} \mathrm{v}$, E-selectin), and specific components of the extracellular matrix (vitronectin, fibronectin, laminin, vWF). It has been reported that $\alpha_{v} \beta_{3}$ can bind MMP-2, enabling endothelial cells to degrade and remodel the ECM during their invasion (Eliceiri \& Cheresh, 1999). The $\alpha_{v} \beta_{3}$ receptor is highly expressed on capillary sprouts that invade the fibrin clot. It has been shown that up-regulation of $\alpha_{v} \beta_{3}$ integrin on endothelial cells is mediated by nitric oxide (NO) which also stimulates endothelial cell podokinesis and increases dissolution of the extracellular matrix via the basic fibroblast growth factor-induced up-regulation of urokinasetype plasminogen activator. VEGF up-regulates expression of endothelial nitric oxide synthase (eNOS) mRNA providing a mechanism for prolonged VEGF-induced NO production (Cooke \& Losordo, 2002).

Remodeling constitutes the final stage of wound healing, where granulation tissue is converted into mature connective tissue and/or scar. The vascularity and cellularity of the wound decrease while the extracellular matrix is reshaped by cross-linking of collagen (Parks, 1999). Although the new collagen increases the tensile strength of the wound, scar tissue can only be $80 \%$ as strong as unwounded skin (Tyrone et al., 2000). During this phase, fibronectin gradually disappears and hyaluronic acid and other glycosaminoglycans are replaced by proteoglycans. This process is regulated by PDGF, TGF- $\beta$, FGF and many other factors. Subsequent wound healing is accompanied by elimination of fibroblasts and macrophages by
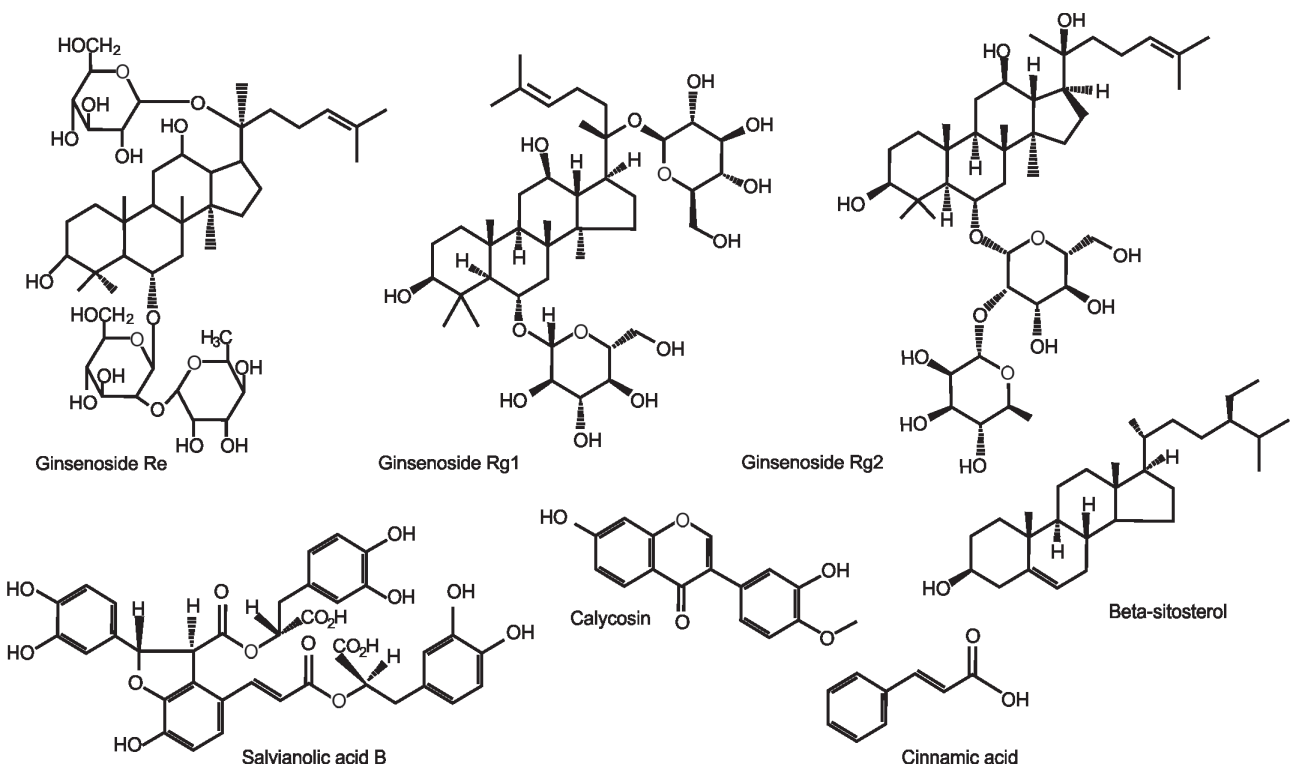

Figure 1. Proangiogenic compounds isolated from plants. 
apoptosis. The growth of capillaries stops with time, the healing area is no longer supplied with blood at an increased rate, and the metabolic activities at the wound site decrease. The wound healing process culminates in a fully matured scar with a decreased number of cells and blood vessels (Velnar et al., 2009).

\section{PLANT-DERIVED STIMULATORS OF ANGIOGENESIS}

Research on wound healing drugs is a developing area in modern biomedical sciences and the search for compounds derived from plants constitutes a significant part of such studies. The use of plants and their extracts has its roots firmly embedded in the ancient civilizations of the East and Africa as well as those of Native American and Native South American cultures. More than $50 \%$ of all drugs in clinical use having a natural product origin show the importance of plants as a source of therapeutic agents (Balandrin et al., 1993). The stimulation of wound healing with herbal products is generally characterized by its high acceptability and good toleration (Jagetia et al., 2003). However, more hard data are necessary for a majority of proangiogenic plant-derived products, especially that most studies concern their antiangiogenic properties (Dulak, 2005). Although many natural products have been claimed to have healing effects, most do not have well-controlled scientific data. They need to be characterized in respect to the active chemical compounds, elucidation of the molecular mechanisms of their actions, demonstration of the real efficacy by in vivo studies and, finally, demonstration of their safety and effectiveness in clinical trials. A number of plants and their extracts are being investigated at present in this direction. Natural agents induce healing by multiple mechanisms, and in this review, medicinal plants as a source of novel angiomodulators stimulating angiogenesis are discussed. The primary challenge for wound healing improvement is to develop a vascular supply that can support the metabolic needs of the regenerated tissues. Products derived from a wide range of plants discussed below are known to have proangiogenic activities.

\section{Panax ginseng}

Panax ginseng (Araliaceae family) has been the most widely used herbal medicine in Eastern Asia for more than 2000 years (Attele et al., 1999). Ginseng has multiple pharmacological actions for treating cardiovascular diseases, rheumatoid arthritis, and in the repair of intractable skin ulcers of patients with diabetes mellitus (Huang et al., 2005, Morisaki et al., 1995). Until now, twelve species have been identified in the genus Panax (Yue et al., 2007). Among them, Panax ginseng C. A. Meyer (Chinese, Asian or Korean ginseng) cultivated in China, Korea, Japan, Russia, and the US, P. quinquefolium L (American ginseng), grown in southern Canada and the US, and $P$. notoginseng (Sanqi ginseng), cultivated in the Yunnan and Guangxi provinces in China are the most extensively studied. The primary active components of ginseng are saponins including more than 40 identified ginsenosides classified as panaxdiols or panaxtriols ( $\mathrm{Lu}$ et al., 2009). The ginseng root contains $2-3 \%$ ginsenosides of which $\mathrm{Rb} 1$ and $\mathrm{Rg} 1$ are the most abundant (Sengupta et al., 2004). The mass-spectroscopic compositional analysis performed by Sengupta et al. has revealed that Rg1 and $\mathrm{Rb} 1$ are present in all investigated extracts, however, each extract displays distinct ginsenoside composition, especially in the ratio between the two. American ginseng has a higher content of ginsenosides than other ginseng species. Extracts from American and Chinese ginseng have a predominance of Rb1 in contrast to Sanqi ginseng with its predominant ginsenoside Rg1. The ratio of Rg1 and Rb1 is especially important in the context of their opposite effects on angiogenesis: the dominance of $\mathrm{Rg} 1$ leads to angiogenesis, whereas Rb1 dominance exerts an opposing effect. Hong and coworkers (2009) have determined the angiogenic activity of total saponins from $P$. notoginseng (containing 11 saponins). Using human umbilical vein endothelial cells (HUVEC) as an in vitro model for studies on angiogenesis they have shown that the extract stimulates proliferation and tube formation by the cells. $P$. notoginseng saponins also stimulate VEGF and KDR/Flk-1 mRNA expression. The results obtained by Hong and coworkers suggest that the proangiogenic effects involve the VEGF-KDR/Flk-1 and PI3K-AkteNOS signaling pathways. It has also been demonstrated that Rg1 alone increases cell proliferation, migration and tube formation, and its angiogenic activities have been confirmed in vivo (Liang et al., 2005; Yue et al., 2005). Sengupta and coworkers (2004) have revealed that Rg1 (Fig. 2) promotes functional neovascularization through the expression of eNOS and the PI3K/Akt pathway. In contrast, Rb1 inhibits invasion of endothelial cells - the earliest step in angiogenesis. In that study neither Rg1 nor Rb1 had any effect on the mitogen-activated protein kinase pathway.

Previously, Rg1 had been demonstrated to trigger transcriptional activation of a glucocorticoid responsive element-containing reporter gene, suggesting that Rg1 can activate glucocorticoid receptor (GR) (Lee et al., 1997). Further studies by Leung et al. (2006) elucidated the effects of Rg1 on the eNOS system. They have shown in HUVECs that Rg1, being a functional ligand of GR, increases phosphorylation and the activities of PI3K, Akt and eNOS, leading to increased NO production. Additionally, Rg1 ginsenoside downregulates the expression of adhesion molecules such as intercellular adhesion molecule-1, vascular cell adhesion molecule-1, and E-selectin (Lü et al., 2004), and upregulates a set of genes related to cell adhesion, migration and cytoskeleton such as RhoA, RhoB, IQ-motifcontaining GTPase activating protein 1, calmodulin, Vav2 and laminin- $\alpha 4$ (Yue et al., 2005). Ma et al. (2006) have also reported that in TNF- $\alpha$-stimulated HUVECs the expression level of mitogen-activated protein kinase kinase kinase 3, reticulocalbin, phosphoglycerate mutase, 6-phosphogluconolactonase, zinc finger protein, nephritis strain-associated protein 1 , and recombination-activating protein is increased, while that of eNOS and mineralocorticoid receptor is decreased. However, Rg1 could prevent these changes or reverse them to some degree. By acting on GR, Rg1 is also a potent stimulator of VEGF expression and this induction is mediated through a PI3K/Akt and $\beta$-catenin/T-cell factor-dependent pathway (Leung et al., 2006). PI3K/ Akt and glycogen synthase kinase $3 \beta$ are signaling molecules necessary for the Rg1-mediated up-regulation of $\beta$-catenin, its translocation into the nucleus, and changes in VEGF expression in HUVECs. Recently Cheung and coworkers (2011) have also shown that in the presence of $\mathrm{Rg} 1, \mathrm{GR}$ and FGFR-1 cooperate to activate a non-genomic signaling cascade that results in angiogenic activity.

Re and Rg2 (Fig. 2), other ginsenosides isolated from different species of Panax, could be also considered as proangiogenic agents. They enhance proliferation, mi- 


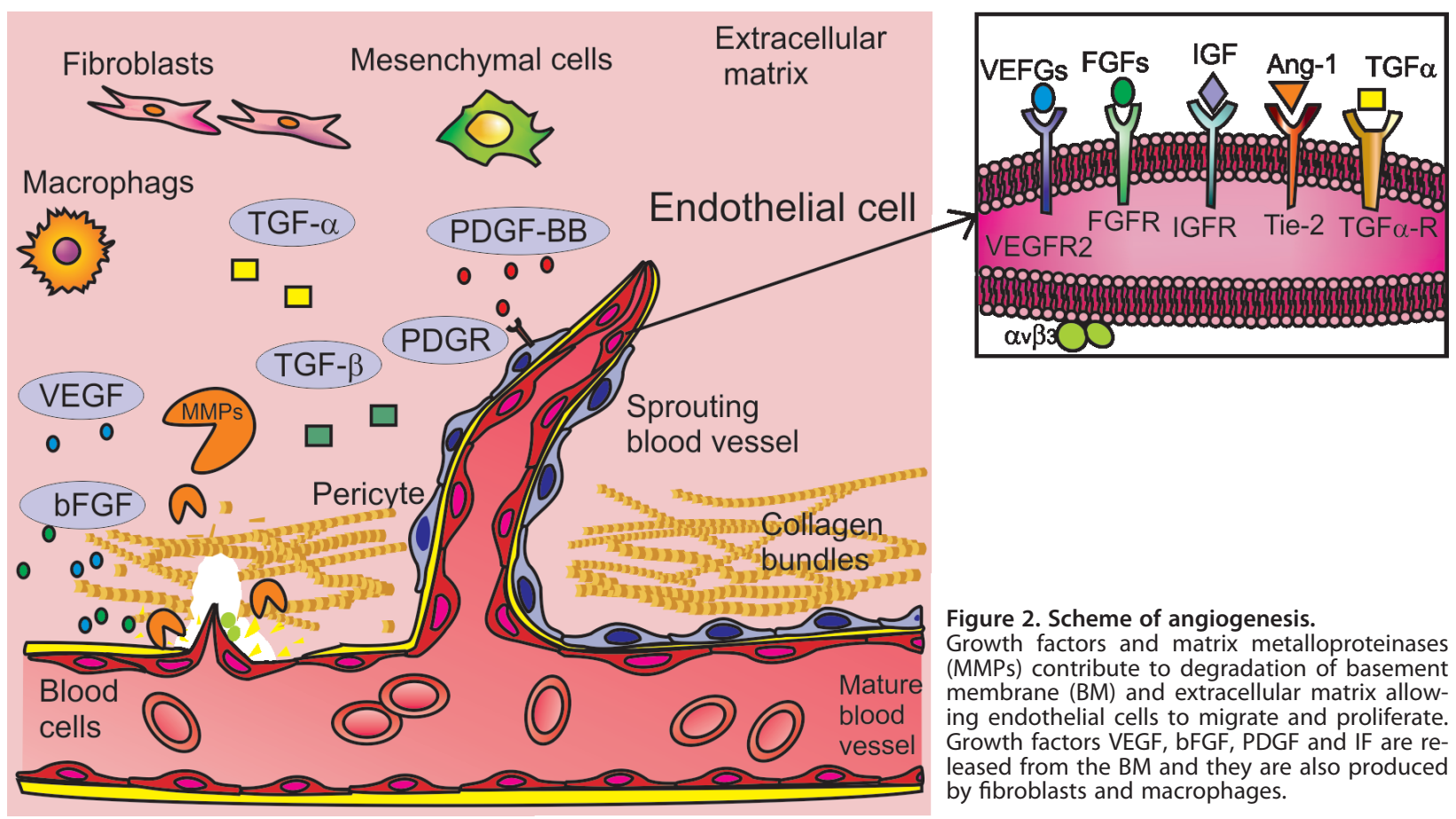

gration, and tube formation of HUVECs (Huang et al., 2005; Yue et al., 2007; Xin et al., 2006). Additionally, in vivo results show that $\mathrm{Re}$ incorporated into a genipinfixed porous acellular bovine pericardium stimulates neovascularization in rats (Huang et al., 2005).

The above data suggests that the natural ginsenosides $\operatorname{Rg} 1, \operatorname{Re}$ and $\operatorname{Rg} 2$ isolated from Panax species may be used for the management of wounds.

\section{Aloe vera}

Aloe vera is a perennial tropical succulent belonging to the Liliaceae family. Although worldwide more than 360 species are known, only a few are currently used by the pharmaceutical and cosmetic industries. Among them, Aloe barbadensis, commonly called Aloe vera, has been one of the most widely used healing plants in history (Lee et al., 1995). A number of studies have demonstrated positive effects of topical application of $A$. vera on burns and other cutaneous injuries (Davis et al., 1987, 1989, Maenthaisong et al., 2007). Recently, $A$. vera has been proven to accelerate the healing of open wounds in type 2 diabetic radiation-exposed rats when administered orally (Atiba et al., 2010, 2011). Immunohistochemical results have revealed that both TGF- $\beta 1$ and VEGF-positive cells are increased in $A$. vera-treated animals. Aloe vera contains over 100 compounds belonging to glycoproteins, saccharides, anthraquinones, and other low-molecular-weight substances. Among the lowmolecular-weight components beta-sitosterol has been identified as an angiogenic factor that may be beneficial to the healing process (Moon et al., 1999). They have demonstrated that crude $A$. vera extract and especially beta-sitosterol stimulate migration of HUVEC cells, show a potent angiogenic activity on the chorioallantoic membrane (CAM) of chick embryos and stimulate neovascularization in the mouse matrigel plug assay (1999). Beta-sitosterol (Fig. 2) from $A$. vera also enhances new vessel formation in gerbil brain damaged by ischaemia/ reperfusion, especially in the cingulated cortex and septal regions, in a dose-dependent fashion. In addition, betasitosterol enhances the expression of proteins related to angiogenesis, vWF, VEGF, VEGF receptor Flk-1, and blood vessel matrix laminin (Choi et al., 2002). Besides beta-sitosterol, other active components of $A$. vera have been demonstrated to influence angiogenesis. Lee and coworkers (1995) have reported that low-molecularweight components from a dichloromethane extract of freeze-dried $A$. vera gel stimulate angiogenesis in chick embryo CAM assay. Furthermore, a methanol-soluble fraction (F3) of the gel deserves special attention as it stimulates proliferation and differentiation of artery endothelial cells and increases invasion of calf pulmonary artery endothelial cells into matrigel (Lee et al., 1998). Moreover, the active F3 fraction enhances expression of proteolytic enzymes, especially urokinase-type plasminogen activator and MMP-2, playing a major role in extracellular matrix degradation (Lee et al., 1998). Also acemannan $(\beta-(1,4)$-acetylated polymannose) - the major polysaccharide of $A$. vera — stimulates expression of VEGF and other wound healing-related factors (e.g., keratinocyte growth factor-1 and type I collagen) in gingival fibroblasts (Jettanacheawchankit et al., 2009). This can be especially beneficial in the case of oral wound healing. Thus, crude Aloe vera extract or isolated proangiogenic components may have potential pharmaceutical applications for the management of wounds.

\section{Hippophae rhamnoides L.}

Hippophae rhamnoides L. (family Elaeagnaceae) commonly known as seabuckthorn (SBT) is a deciduous shrub native to Europe and Asia (Li \& Beveridge, 2003). Leaves, ripe fruits and seeds from seabuckthorn have been found to be a rich source of a large number of bioactive substances including flavonoids (isorhamnetin, quercetin, myricetin, kaempferol and their glycoside derivatives), carotenoids ( $\alpha, \beta, \delta$-carotene, lycopene), vitamins (A, $\mathrm{C}, \mathrm{E}$ and $\mathrm{K})$, tannins, triterpenes, glycerides of palmitic, stearic and oleic acids and some essential amino acids (Beveridge et al., 1999; Zu et al., 2006). The high content 
of bioactive substances has been reflected in its extensive exploitation by traditional medicine. Seabuckthorn has antioxidant (Upadhyay et al., 2010) and anti-inflammatory activity (Ganju et al., 2005) and has been reported to be useful in treating skin wounds (Upadhyay et al., 2009a), cardiovascular diseases (Eccleston et al., 2002), thrombosis and platelet aggregation (Cheng et al., 2003).

Several studies have also demonstrated an angiogenic activity of $H$. rhamnoides (Gupta et al., 2008; Upadhyay et al., 2010). Upadhyay et al. (2010) have indicated that lyophilized aqueous leaf extract of seabackthorn promotes wound healing in experimental burn wounds and has a positive influence on different phases of wound repair, including angiogenesis. That investigation has shown that SBT treatment stimulates angiogenesis in both in vivo and in vitro models as indicated by histological studies and new vessel formation in chick embryo chorioallantoic membrane model. STB up-regulates VEGF as well as MMP-2 and MMP-9 expression (Ferrara, 1999; Upadhyay et al., 2010). One of the active proangiogenic compounds may be sitosterol which constitutes $57-76$ and $61-83 \%$, respectively, of the seed and pulp/ peel sterols of the two major subspecies of $H$. rhamnoides: sinensis and rhamnoides (Yang et al., 2001).

Studies concerning Hippophae rhamnoides L., Aloe vera L. and Curcuma longa L. have separately shown positive results in wound healing. Gupta et al. (2008) investigated the wound healing activity of a poly-herbal formulation (PHF) prepared by combining aqueous lyophilized leaf extracts of $H$. rhamnoides $\mathrm{L}$. and $A$. vera $\mathrm{L}$. and the ethanol rhizome extract of $C$. longa L., in an optimized ratio $(1: 7: 1)$. Topical PHF treatment brought about an increase of VEGF expression as well as in vitro promotion of angiogenesis in the CAM model. However, the promising results showed by Gupta and coworkers need to be further evaluated. It is unknown if the PHF efficacy is due to specific phytoconstituents of one of the plants or is a synergic effect of all components.

\section{Angelica sinensis}

Angelica sinensis (Apiaceae family) is a key component of the traditional Chinese medicine and, next to ginseng, is one of the most popular herbs. The root of $A$. sinensis is recommended for women for balancing and relief of discomforts such as dysmenorrhea, irregular menstruation, anemia, constipation and abdominal pain (Ososki \& Kennelly, 2003). A. sinensis contains many bioactive components including ferulic acid (FA), ligustilide, senkyunolide H, senkyunolide I (Lao et al., 2004; Dong et al., 2005), 3-butylphthalide (Li et al., 2006) and polysaccharides (Ye et al., 2003). Dong and coworkers (2004) have demonstrated positive effect of $A$. sinensis on inhibition of platelet activation, repair of vascular EC injury, and on improvement of microcirculation in ulcerative colitis. Polysaccharides extracted from $A$. sinensis significantly promote the migration of gastric epithelial cells over an artificial wound (Ye et al., 2001a). Ye and coworkers (2001b) suggest that ornithine decarboxylase and c-Myc protein are closely associated with $A$. sinensis improvement of mucosal healing. To date, studies on $A$. sinensis in the context of angiogenesis have shown some discrepancies. Meng et al. (2008) have reported that extracts from Angelica and ChuanXiong could affect VEGF expression in rat myocardial infarction, promote endothelial cell proliferation and increase the number of vessels in chick embryo chorioallantoic membrane models, suggesting that these two herbs have angiogenic activity.
Similarly, a study by Lam and colleagues (2008) has indicated that an aqueous extract of $A$. sinensis root enhances HUVEC proliferation, migration, invasion and tube formation on matrigel as well as promotes angiogenesis in vivo in zebrafish. This extract promotes angiogenesis through enhancing VEGF expression and stimulating cJun N-terminal kinases 1 and 2 (JNK1/2) and p38 phosphorylation to control cell proliferation, viability, and morphogenesis. The above studies are in contrast to a recent investigation by Yeh et al. (2011). They have demonstrated that a volatile oil of $A$. sinensis Radix and one of its bioactive components ( $n$-butylidenephthalide) have antiangiogenic properties through inhibition of cell cycle progression and induction of apoptosis. However, it has to be mentioned that aqueous extract of $A$. sinensis Radix contains mainly polysaccharides $(60 \%)$, although ferulic acid, Z-ligustilide and $n$-butylidenephthalide are also detected (Lam et al., 2008). On the other hand, volatile oil consists of monoterpenes and sesquiterpenes, and neither ferulic acid nor polysaccharide could be detected (Yeh et al., 2011). These findings suggest that distinct constituents present in the different extracts of Angelica sinensis Radix are the main reason of the contrasting effects on angiogenesis. This is similar to the opposite activities of $\mathrm{Rg} 1$ and Rb1 ginsenosides extracted from various Panax species (Huang et al., 2005; Yue et al., 2005).

\section{Astragalus membranaceus}

Radix Astragali is the dried root of Astragalus membranaceus (Fisch) Bunge or Astragalus membranaceus var. mongholicus (Bunge) Hsiao (Fabaceae family) (Xiao \& Liu, 1999). It is one of the 50 fundamental herbs of traditional Chinese medicine (Hoo et al., 2010) with a beneficial effect for the strengthening the immune system and for treatment of influenza, abnormal uterine bleeding, diabetes mellitus, and cardiovascular diseases (WHO, 1999). Pharmacological studies have demonstrated cardioprotective effect of Radix Astragali against heart failure (Zhao et al., 2009), myocardial infarction ( $\mathrm{Xu}$ et al., 2008), chronic hepatitis (Tang et al., 2009), and diabetes (Lau et al., 2009). Chemical and biological investigations on Radix Astragali have identified three major bioactive groups of constituents: isoflavonoids (including formononetin, calycosin, ononin and their glucosides), triterpene saponins (astragalosides I-IV), and polysaccharides (Ma et al., 2002).

Radix Astragali has also been shown to have proangiogenic activity. Zhang et al. (2009) have demonstrated that Radix Astragali extract stimulates HUVEC to proliferate and enhances their motility in the wound healing migration assay via enhancing VEGF mRNA expression and activation of the PI3K-Akt-eNOS pathway. They show that inhibitors of the VEGF-KDR/Flk strongly diminish the effect of Radix Astragali extract, suggesting that proangiogenic effects involve the VEGF-KDR/Flk pathway. The compositions of Radix Astragali extract includes formononetin, calycosin, (6aR, 11aR)-9,10-dimethoxy3-hydroxypterocarpan and saponins (astragaloside I, II and IV) comprising $8.15 \%, 0.77 \%, 0.01 \%$ and $0.88 \%$ of the whole extract, respectively. However, calycosin (Fig. 2.) has been found to be the most potent proangiogenic agent among all. Further studies have revealed that calycosin acts as a selective estrogen receptor modulator (Tang et al., 2010). It has been shown that phytoestrogens are able to bind to the both isoforms of estrogen receptor (ER) ER $\alpha$ and ER $\beta$ (Kostelac et al., 2003). Moreover, $\mathrm{ER} \alpha$ binds to PI3K, and the stimulation with estrogen leads to activation of the PI3K-Akt-eNOS sig- 
naling pathway (Simoncini et al., 2000). Tang and coworkers (2010) have shown that calycosin competitively binds to $E R \alpha$ and $E R \beta$ as well as selectively modulates ER transcriptional activities. Activation of $E R \alpha$ and $E R \beta$ may affect expression of VEGF and VEGF receptors (Albrecht et al., 2003). Indeed, calycosin has been shown to induce angiogenesis in HUVECs in vitro and in zebrafish embryos in vivo via the up-regulation of expression of VEGF, Flt-1 and KDR/Flk-1 mRNA. Furthermore, calycosin promotes angiogenesis via activation of MAPK signaling pathways with an involvement of extracellularsignal-regulated kinases 1 and 2 (ERK1/2) (Tang et al., 2010).

Recent data indicate that Radix Astragali-derived flavonoids including formononetin, ononin, calycosin, and calycosin-7-O- $\beta$-D-glucoside increase the level of the inducible subunit of hypoxia-inducible factor mRNA and protein. HIF- $1 \alpha$ is a transcription factor that modulates a wide range of processes, including angiogenesis (Zheng et al., 2011). Besides, the above flavonoids reduce the degradation of HIF-1 $\alpha$ significantly increasing its level. However, none of the flavonoids induces the phosphorylation of ERK.

The cited studies show promise for further development of Radix Astragali as a therapeutic agent for the treatment of wounds and angiogenesis deficiencies. Nevertheless, more research has to be done to accept Radix Astragali extract as a regular medicine.

\section{Other examples}

Cinnamomum cassia is also one of the medicinal plants that have been used to ease the symptoms of various diseases caused by insufficient vascularization or by insufficient blood circulation. However, only one investigation has been conducted so far on the angiogenic effect of $C$. cassia and its active compound cinnamic acid (Fig. 2). Choi et al. (2009) have proven that ethanol extract of $C$. cassia and cinnamic acid induce angiogenesis in vivo and in vitro by increasing the production of VEGF and up-regulation of Flk-1/KDR receptor expression. Furthermore, the compounds tested increased the vWF antigen expression and hemoglobin contents, which paralleled the onset of angiogenesis and is considered an early indicator of endothelial activation. Similarly to the case of $C$. cassia, despite the beneficial effects in wound healing only single papers have appeared reporting angiogenic activity of extracts from Stewartia koreana leaves (Lee et al., 2010), Uncaria rbynchophylla (Choi et al., 2005), Patrinia villosa (Jeon et al., 2010), Pueraria montana (Chung et al., 2010), Rehmannia glutinosa (Lau et al., 2009) and Salvia miltiorrbiza (Lay et al., 2003a, Lay et al., 2003b; Wu et al., 2010). In all cases significant stimulation of proliferation and migration of HUVECs was observed, which was due to activation of different signaling pathways (Table 1).

\section{DISCUSSION}

Currently great efforts are being made to study angiogenesis. In 1994, The Angiogenesis Foundation (http:// www.angio.org) declared angiogenesis a 'common denominator' in the most important diseases of the society. This is due to the fact that disruption of angiogenesis leads to pathological states. Thus, excessive angiogenesis contributes to tumor growth, diabetic retinopathy, age-related macular degeneration, psoriasis and endometriosis, and insufficient angiogenesis leads to chronic wounds, coronary artery disease and ischemic heart disease. The intense interest in angiogenesis has resulted in the identification and characterization of at least 20 proangiogenic and more than 30 antiangiogenic factors as well as numerous receptors and signaling partners (Tombran-Tink \& Barnstable, 2006). Insufficient angiogenesis is caused by an inadequate production of angiogenesis growth factors and/or excessive amounts of angiogen-

Table 1. Proangiogenic activity of Panax sp. extracts and isolated ginsenosides

\begin{tabular}{|c|c|c|c|c|c|}
\hline Species & Common name & Compound & $\begin{array}{l}\text { Long-term effects } \\
\text { activated }\end{array}$ & Mechanism of action & References \\
\hline Panax notoginseng & Sanqi ginseng & $\begin{array}{l}\text { Saponin extract } \\
\text { of R1, Rg1, Re, } \\
\text { Rf, Rg2, b1, Rc, } \\
\text { Rb2, b3, Rd, } \\
\text { Rg3 }\end{array}$ & $\begin{array}{l}\text { Proliferation and } \\
\text { tube formation of } \\
\text { HUVEC }\end{array}$ & $\begin{array}{l}\text { Enhancing VEGF and KDR/ } \\
\text { Flk-1 expression; activation } \\
\text { of PI3K-Akt-eNOS signaling } \\
\text { pathway }\end{array}$ & Hong et al., 2009 \\
\hline Panax ginseng & $\begin{array}{l}\text { Asian ginseng } \\
\text { Chinese ginseng }\end{array}$ & $\begin{array}{l}\text { Korean red } \\
\text { ginseng water } \\
\text { extract of } \mathrm{Rb} 1 \text {, } \\
\mathrm{Rb} 2, \mathrm{Rc}, \mathrm{Rd}, \mathrm{Re}, \\
\mathrm{Rf}, \mathrm{Rg} 1, \mathrm{Rg} 2, \\
\mathrm{Rg} 3\end{array}$ & $\begin{array}{l}\text { Proliferation, mi- } \\
\text { gration, and tube } \\
\text { formation of HUVEC; } \\
\text { angiogenesis in vivo }\end{array}$ & $\begin{array}{l}\text { Activation of the PI3K/ } \\
\text { Akt-dependent ERK } 1 / 2 \text { and } \\
\text { eNOS } \\
\text { signaling pathways }\end{array}$ & Kim et al., 2007 \\
\hline Panax sp. & & Pure Rg1 & $\begin{array}{l}\text { Proliferation, mi- } \\
\text { gration and tube } \\
\text { formation of HUVEC; } \\
\text { endothelial spro- } \\
\text { uting in the ex vivo } \\
\text { rat aorta ring assay; } \\
\text { angiogenesis in vivo }\end{array}$ & $\begin{array}{l}\text { Decreased expression of } \\
\text { ICAM-1, VCAM-1, } \\
\text { E-selectin; increased } \\
\text { expression of VEGF, RhoA, } \\
\text { RhoB, Vav2, IQGAP1, } \\
\text { CALM2, LAMA4; PI3K-Akt- } \\
\text { eNOS signaling pathway; } \\
\text { triggering transcriptional } \\
\text { activation of a GRE; } \\
\text { GR-dependent activation } \\
\text { of FGFR-1 }\end{array}$ & $\begin{array}{l}\text { Sengupta et al., } 2004 \\
\text { Lü et al., } 2004 \\
\text { Yue et al., } 2005 \\
\text { Liang et al., } 2005 \\
\text { Leung et al., } 2006 \\
\text { Lee et al., } 1997 \\
\text { Cheung et al., } 2011\end{array}$ \\
\hline Panax sp. & & $\begin{array}{l}\text { Pure } \mathrm{Rg} 2 \text { and } \\
\text { Re }\end{array}$ & $\begin{array}{l}\text { Proliferation, migra- } \\
\text { tion and tube for- } \\
\text { mation of HUVEC; in } \\
\text { vivo angiogenesis }\end{array}$ & $\begin{array}{l}\text { PI3K-Akt-eNOS signaling } \\
\text { pathway }\end{array}$ & $\begin{array}{l}\text { Huang et al., 2005; } \\
\text { Yu et al., 2007, } \\
\text { Xin et al., } 2006 \\
\text { Furukawa et al., } 2006\end{array}$ \\
\hline
\end{tabular}


Table 2. Proangiogenic activity of compounds isolated from different sources

\begin{tabular}{|c|c|c|c|c|c|}
\hline Species & $\begin{array}{l}\text { Common } \\
\text { name }\end{array}$ & Family & Compound & Mechanism of action & References \\
\hline $\begin{array}{l}\text { Aloe barba- } \\
\text { densis }\end{array}$ & Aloe vera & Liliaceae & $\begin{array}{l}\text { lyophilized powder } \\
\text { methanol-soluble frac- } \\
\text { tion (F3) of the gel } \\
\beta \text {-Sitosterol } \\
\text { acemannan }\end{array}$ & $\begin{array}{l}\text { Increased expression of TGF- } \beta 1, \text { VEGF } \\
\text { increased expression of u-PA and } \\
\text { MMP-2 } \\
\text { Increased expression of von Wil- } \\
\text { lebrand factor, VEGF, VEGF receptor } \\
\text { Flk-1 and laminin } \\
\text { Increased expression of VEGF }\end{array}$ & $\begin{array}{l}\text { Atiba et al., 2010, } 20011 \\
\text { Lee et al., } 1998 \\
\text { Choi S et al., } 2002 \\
\text { Jettanacheawchankit et } \\
\text { al., } 2009\end{array}$ \\
\hline $\begin{array}{l}\text { Hippophae } \\
\text { rhamnoides }\end{array}$ & $\begin{array}{l}\text { Seabuck- } \\
\text { thorn }\end{array}$ & $\begin{array}{l}\text { Elaeagna- } \\
\text { ceae }\end{array}$ & aqueous leaf extract & $\begin{array}{l}\text { Increased VEGF, MMP-2, MMP-9 ex- } \\
\text { pression }\end{array}$ & $\begin{array}{l}\text { Upadhyay et al., } 2010 \\
\text { Gupta et al., } 2008\end{array}$ \\
\hline $\begin{array}{l}\text { Angelica si- } \\
\text { nensis }\end{array}$ & Dong Quai & Apiaceae & $\begin{array}{l}\text { aqueous extract conta- } \\
\text { ining polysaccharides }\end{array}$ & $\begin{array}{l}\text { Increased VEGF expression; p38 and } \\
\text { JNK } 1 / 2 \text { phosphorylation pathway }\end{array}$ & $\begin{array}{l}\text { Dong et al. 2004; Lam } \\
\text { et al., 2008; Meng et al., } \\
2008\end{array}$ \\
\hline $\begin{array}{l}\text { Cinnamomum } \\
\text { cassia }\end{array}$ & $\begin{array}{l}\text { Chinese } \\
\text { Cinnamon }\end{array}$ & Lauraceae & $\begin{array}{l}\text { ethanol extract and } \\
\text { Cinnamic acid }\end{array}$ & $\begin{array}{l}\text { Increased expression of VEGF and } \\
\text { Flk-1/KDR }\end{array}$ & Choi DY et al., 2009 \\
\hline $\begin{array}{l}\text { Astragalus } \\
\text { membrana- } \\
\text { ceus }\end{array}$ & & Fabaceae & $\begin{array}{l}\text { Radix Astragali extract } \\
\text { with calycosin } \\
\text { Calycosin }\end{array}$ & $\begin{array}{l}\text { Increased VEGF expression HIF-1a } \\
\text { and, activation of PI3K-Akt-eNOS and } \\
\text { VEGF-KDR/Flk pathways } \\
\text { Increased VEGF and KDR/Flk-1 expres- } \\
\text { sion; ERK1/2 activation; ; activation of } \\
\text { ERa and ER } \beta \text { and MAPK signaling }\end{array}$ & $\begin{array}{l}\text { Zhang et al., } 2009 \\
\text { Zheng et al., } 2011 \\
\text { Tang et al., } 2010\end{array}$ \\
\hline $\begin{array}{l}\text { Stewartia } \\
\text { koreana }\end{array}$ & & Theaceae & $\begin{array}{l}\text { methanol extracts le- } \\
\text { aves }\end{array}$ & $\begin{array}{l}\text { Stimulation of ERK phosphorylation } \\
\text { and Akt kinases }\end{array}$ & Lee TH et al., 2010 \\
\hline $\begin{array}{l}\text { Uncaria rhyn- } \\
\text { chophylla }\end{array}$ & Cat's Claw & Rubiaceae & $\begin{array}{l}\text { ethanol extract of } U \text {. } \\
\text { hynchophylla's root }\end{array}$ & $\begin{array}{l}\text { Increased VEGF, and bFGF expression } \\
\text { and protein secretion of }\end{array}$ & Choi DY et al., 2005 \\
\hline $\begin{array}{l}\text { Salvia miltior- } \\
\text { rhiza }\end{array}$ & Danshen & $\begin{array}{l}\text { Lamina- } \\
\text { ceae }\end{array}$ & $\begin{array}{l}\text { crude extract and salvia- } \\
\text { nolic acid B }\end{array}$ & $\begin{array}{l}\text { Increased expression of MMP-2, VEGF, } \\
\text { VEGF-R2 and Tie-1 }\end{array}$ & Lay et al., 2003a, 2003b \\
\hline $\begin{array}{l}\text { Patrinia vil- } \\
\text { losa }\end{array}$ & White P. & $\begin{array}{l}\text { Valeriana- } \\
\text { ceae }\end{array}$ & aqueous extract & $\begin{array}{l}\text { Activation of FAK and Akt signaling } \\
\text { pathway }\end{array}$ & Jeon et al., 2010 \\
\hline $\begin{array}{l}\text { Pueraria mon- } \\
\text { tana }\end{array}$ & Kudzu & Fabaceae & aqueous extract & $\begin{array}{l}\text { Activation of MEK/ERK-, PI3K/Akt/ } \\
\text { eNOS-, and Src/FAK-dependent path- } \\
\text { ways, without altering VEGF expres- } \\
\text { sion }\end{array}$ & Chung et al., 2010 \\
\hline
\end{tabular}

esis inhibitors. Therapeutic angiogenesis, which is aimed at stimulating neovascularization with growth factors, is being developed to reverse these conditions and have been used in clinical trials and animal studies. However, in the field of administration of growth factors in impaired wound healing only one agent has been approved for human use, the recombinant human growth factor $\mathrm{BB}$ of platelet origin (rhPDGF-BB) with market name Regranex $^{\circledR}$ (Fonder et al., 2008).

Extensive research has also been carried out in the area of wound healing through the use of medicinal plants since nature is an inexhaustible reservoir of bioactive substances. The traditional folk medicine has highlighted many plants to have a beneficial impact on wound healing and treatment of ischemic heart diseases. Recently, these plants have been analyzed for their impact on the formation of blood vessels in vitro and in vivo, with special attention given to the influence on VEGF expression. Studies on plants used in traditional medicine have indicated the following species with significant proangiogenic activity: Aloe vera, Hippophae rhamnoides L., Angelica sinensis, Cinnamomum cassia, Astragalus membranaceus, Stewartia koreana, Uncaria rbynchophylla, Salvia miltiorrbiza, Patrinia villosa Juss., Rehmannia glutinosa, and four ginsengs: Panax ginseng, P. schinsen, $P$. notoginseng, and P. quinquefolium (for references see Table 1). Nevertheless, not all of their bioactive components have been isolated and identified. The chemical constituents identified so far belong to polyphenols (cinnamic acid, calycosin, salvianolic acid B), sterols ( $\beta$-sitosterol), and saponins (ginenosides Rg1, Re, Rg2).
The components of plants described in this review enhance the expression of VEGF and its receptor, VEGFR2 (Moon et al., 1999; Choi S et al., 2002; Lay et al., 2003a; 2003b; Choi DY et al., 2005; 2009; Gupta et al., 2008; Lam et al., 2008; Hong et al., 2009; Zhang et al., 2009; Upadhyay et al., 2010; Tang et al., 2010). They are also able to stimulate angiogenesis through the PI3KAkt-eNOS pathway. The PI3K-Akt-eNOS signaling has been known as an important determinant of endothelial cell migration, proliferation, and survival (Dimmeler \& Zeiher, 1999; Urbich \& Dimmeler, 2005). Phosphatidylinositol-3-kinase is an upstream signaling molecule of serine/threonine kinase Akt/protein kinase B. Akt/PKB through phosphorylation of endothelial nitric oxide synthase at Ser1177 stimulates NO production, vasodilation and endothelial cell migration (Somanath et al., 2006).

A second important signaling pathway in angiogenesis is connected with mitogen-activated protein kinases. This pathway is activated by calycosin from Radix Astragali (Tang et al., 2010) and extracts from Angelica sinensis (Lam et al., 2008), Stewardia koreana (Lee et al., 2010), Panax ginseng C. A. Meyer (Kim et al., 2007), and Puerariae montana (Chung et al., 2010). In the case of the last two plant extracts angiogenesis is stimulated through both MAPK-dependent and PI3K-Akt-eNOS signaling pathways. Mitogen-activated protein kinases are a family of serine/threonine protein kinases which regulate a number of cellular activities (Kuida \& Boucher, 2004). Three of the six major subfamilies are especially involved in the growth of blood vessels, and these are extracellular 
signal-regulated kinases (ERK1/2), three JUN-aminoterminal kinases (JNK1/2/3) and four p38 protein kinases $(\mathrm{p} 38 \alpha / \beta / \gamma / \delta)$ (Kuida \& Boucher, 2004). ERK1/2 are activated in response to growth factors, whereas JNKs and p38 are usually activated in response to inflammatory cytokines and cellular stress (Robinson \& Cobb, 1997). In particular, ERK1/2, one of the major targets of the MAPK signaling pathway, plays an important role in endothelial cell migration and proliferation (Tanaka et al., 1999), additionally the ERKs are activated through the three-component protein kinase cascade $\mathrm{Raf} \rightarrow \mathrm{MEK} \rightarrow \mathrm{ERK}$ (Robinson \& Cobb, 1997).

One characteristic of crude plant material is that its constituents may have opposite, moderating or enhancing effects. That is why the final activity depends of the interactions among the constituents and the effect of each constituent on its own. The polyherbal formulation is based on this assumption (Gupta et al., 2008). However, it is important to fully characterize and standardize plant extracts because the compositional ratio may have a significant influence on the result such as a pro- or antiangiogenic effect. In contrast to the antiangiogenic effects of ginsenosides such as Rb1 and $\mathrm{Rg} 3$, Rg1, Re and Rg2 have been found to be proangiogenic. The latter three increase HUVEC proliferation, migration and tube formation (Sengupta et al., 2004; Huang et al., 2005; Xin et al., 2006; Yu et al., 2007). Similarly, Angelica sinensis Radix contains components exerting opposing effects on blood vessel growth (Dong et al., 2004; Meng et al., 2008; Yeh et al., 2011). Aqueous extract of $A$. sinensis Radix contains mainly polysaccharides $(60 \%)$ responsible for proangiogenic activity (Lam et al., 2008), and volatile oil consisting of monoterpenes and sesquiterpenes, among them $n$-butylidenephthalide, has been shown to be antiangiogenic (Yeh et al., 2011). These examples emphasize the importance of characterizing active substances present in particular plant extracts for the development of novel angiogenesis modulators as well as the need for standardization of plant-derived medicines, including their methods of preparation. However, elucidation of the molecular signals and pathways that are activated by plant constituents seems to be important as well. The example of resveratrol (trans-3,5,4'-trihydroxy stilbene) is particularly interesting. This natural polyphenol primarily extracted from grape and mulberry reveals contrasting effects on angiogenesis that is situation-dependent. In the literature resveratrol is predominantly known as an antitumor agent. However, among the various functions attributed to resveratrol, its influence on angiogenesis is particularly astonishing. Resveratrol has been demonstrated to have anti-angiogenic effects, mainly observed in tumors. It inhibits proliferation of bovine pulmonary artery endothelial cells and HUVECs by inhibition of bFGF- and VEGF-receptor-mediated capillary endothelial cell growth and by increasing p53 protein expression. Also scavenging of reactive oxygen species by resveratrol may contribute to its anti-angiogenic effects. Resveratrol also inhibits formation of new blood vessels in vivo, especially during tumor growth (Dulak, 2005; Chen \& Tseng, 2007). In addition to its anticancer and anti-angiogenic activity, resveratrol displays a cardioprotective effect. It has been shown that resveratrol protects perfused rat hearts through an increase in inducible nitric oxide synthase (iNOS) (Hattori et al., 2002). Besides, resveratrol enhanced myocardial angiogenesis both in vivo and in vitro by induction of VEGF, which was regulated by thioredoxin-1 (Trx-1) and heme oxygenase-1 (HO-1). Furthermore, pretreatment of rats with resveratrol (1 $\mathrm{mg} / \mathrm{kg} / \mathrm{day})$ for 2 weeks reduced infarct size $24 \mathrm{~h}$ after myocardial infarction and increased capillary density in the peri-infarct myocardium (Kaga et al., 2005). A strong increase in VEGF, its receptor Flk-1, iNOS, eNOS and redox-regulated transcription factors $\mathrm{NF}-x \mathrm{~B}$ in the resveratrol-treated myocardium was demonstated by Fukuda et al. (2006). Resveratrol improves postischemic ventricular function, reduces myocardial infarction and cardiomyocyte apoptosis, activates survival signal, and reduces death signal (Mukherjee et al., 2010). So resveratrol can function both as a pro-angiogenic and anti-angiogenic agent. The dosage and pharmacokinetics of resveratrol but also the cell type are important factors in determining whether it exerts a pro- or antiangiogenic effect (Chen \& Tseng, 2007; Mukherjee et al., 2010). At low concentrations resveratrol appears to increase cell proliferation, whereas apoptosis is induced in various cancer cells at higher concentrations. Resveratrol administered at $10-20 \mathrm{mg} / \mathrm{kg}$ or $5-10 \mu \mathrm{M}$ is usually effective to exert protective effects against ischemia-reperfusion injury whereas studies on cancer prevention reveal that resveratrol has to be used at higher concentrations (e.g., $40 \mathrm{mg} / \mathrm{kg} /$ day of resveratrol treatment decreases angiogenesis and inhibits tumor growth in gliomas). Taking into account this dose- dependency, resveratrol can be classified as an example of hormetins - mild stress-inducing molecules. The term "hormesis" was introduced by Goldman (1996) to mean "the beneficial effect of a low level exposure to an agent that is harmful at high levels". Another example of a hormetic plant-derived molecule is curcumin (diferuloylmethane) - the active component in the food spice turmeric isolated from the roots of Curcuma longa. Administration of curcumin at the dosage of $100 \mathrm{mg} / \mathrm{kg}$ body weight resulted in induction of vascularization in rats (Jagetia \& Rajanikant, 2003). In mice down-regulation of expression of angiogenic factors was most consistently observed and sustained at $24 \mathrm{~h}$ after treatment using the $500 \mathrm{mg} / \mathrm{kg}$ dose (Lin et al., 2007). Clinical trials have demonstrated that curcuma extract can be administered safely to patients at doses of up to $2.2 \mathrm{~g}$ daily, equivalent to 180 $\mathrm{mg}$ of curcumin. However, the main limiting factor is low oral bioavailability in humans and additional intestinal metabolism (Sharma et al., 2001).

The plants reviewed here play an important role in folk medicine. The information about their beneficial effects on wound healing and on the circulatory system comes from the centuries-long tradition. In the development of pharmacological agents there is a need to elucidate the mechanism of their action. The evaluation of angiogenic effects of natural products led to the development of the anticancer drug Taxol $^{\circledR}$, originally obtained from Pacific yew tree (Taxus brevifolia) (Fan et al., 2006). Hence, plant extracts and natural compounds are of substantial interest to researchers as the candidates for novel drugs. The authors cited in this review have shown in in vitro and in vivo studies the proangiogenic effects of plant extracts and suggested the mechanisms by which they activate the angiogenesis. Despite those promising results more detailed research and thorough standardization of plant extract are necessary to offer novel wound healing therapy. This review indicates the importance of study of the plant effects on angiogenesis not only because of the widely described antiangiogenic effects, but also due to the proangiogenic activity in wound healing and cardiovascular diseases. 


\section{Acknowledgements}

This work was supported by a grant (N N312 340740) from the Ministry of Science and Higher Education.

\section{REFERENCES}

Albrecht ED, Babischkin JS, Lidor Y, Anderson LD, Udoff LC, Pepe GJ (2003) Effect of estrogen on angiogenesis in co-cultures of human endometrial cells and microvascular endothelial cells. Hum Reprod 18: 2039-2047.

Atiba A, Nishimura M, Kakinuma S, Hiraoka T, Goryo M, Shimada Y, Ueno H, Uzuka Y (2011) Aloe vera oral administration accelerates acute radiation-delayed wound healing by stimulating transforming growth factor- $\beta$ and fibroblast growth factor production. Am J Surg 201: 809-818.

Atiba A, Ueno H, Uzuka Y (2011) The effect of aloe vera oral administration on cutaneous wound healing in type 2 diabetic rats. $J$ et Med Sci 73: 583-589.

Attele AS, Wu JA, Yuan CS (1999) Ginseng pharmacology multiple constituents and multiple actions. Biochem Pharmacol 58: 1685-1693.

Balandrin MF, Kinghorn AD, Farnsworth NR (1993) Plant-Derived Natural Products in Drug Discovery and Development In Human Medicinal Agents from Plants, Kinghorn AD, Balandrin MF ed. ACS Symposium Series 534, pp 2-12. Washington, DC.

Beveridge T, Li TS, Oomah BD, Smith A (1999) Sea buckthorn products: manufacture and composition. J Agric Food Chem 47: 34803488 .

Carmeliet P (2000) Mechanisms of angiogenesis and arteriogenesis. Nat Med 6: 389-395.

Chen Y, Tseng SH (2007) Review. Pro- and anti-angiogenesis effects of resveratrol. In Vivo 21: 365-370.

Chen J, Somanath PR, Razorenova O, Chen WS, Hay N, Bornstein P, Byzova TV (2005) Akt1 regulates pathological angiogenesis, vascular maturation and permeability in vivo. Nat Med 11: 1188-1196.

Cheng J, Kondo K, Suzuki Y, Ikeda Y, Meng XS, Umemura K (2003) Inhibitory effects of total flavones of Hippophae rhamnoides $L$. on thrombosis in mouse femoral artery and in vitro platelet aggregation. Life Sci 72: 2263-2271.

Cheung LW, Leung KW, Wong CK, Wong RN, Wong AS (2011) Ginsenoside-Rg1 induces angiogenesis via non-genomic crosstalk of glucocorticoid receptor and fibroblast growth factor receptor-1. Cardiovasc Res 89: 419-425.

Chiarugi P, Cirri P (2003) Redox regulation of protein tyrosine phosphatases during receptor tyrosine kinase signal transduction. Trends Biochem Sci 28: 509-514.

Choi DY, Baek YH, Huh JE, Ko JM, Woo H, Lee JD, Park DS (2009) Stimulatory effect of Cinnamomum cassia and cinnamic acid on angiogenesis through up-regulation of VEGF and Flk-1/KDR expression. Int Immunopharmacol 9: 959-967.

Choi DY, Huh JE, Lee JD, Cho EM, Baek YH, Yang HR, Cho YJ, Kim KI, Kim DY, Park DS (2005) Uncaria rbynchophylla induces angiogenesis in vitro and in vivo. Biol Pharm Bull 28: 2248-2252.

Choi S, Kim KW, Choi JS, Han ST, Park YI, Lee SK, Kim JS, Chung $\mathrm{MH}$ (2002) Angiogenic activity of beta-sitosterol in the ischaemia/ reperfusion-damaged brain of Mongolian gerbil. Planta Med 68: 330335.

Chung BH, Cho YL, Kim JD, Jo HS, Won MH, Lee H, Ha KS, Kwon YG, Kim YM (2010) Promotion of direct angiogenesis in vitro and in vivo by Puerariae flos extract via activation of MEK/ERK-, PI3K/Akt/eNOS-, and Src/FAK-dependent pathways. Phytother Res 24: 934-940.

Cooke JP, Losordo DW (2002) Nitric oxide and angiogenesis. Circulation 105: 2133-2135.

Cross MJ, Claesson-Welsh L (2001) FGF and VEGF function in angiogenesis: signalling pathways, biological responses and therapeutic inhibition. Trends Pharmacol Sci 22: 201-207.

Davis RH, Kabbani JM, Maro NP (1987) Aloe vera and wound healing. $J$ Am Podiatr Med Assoc 77: 165-169.

Davis RH, Leitner MG, Russo JM, Byrne ME (1989) Wound healing. Oral and topical activity of Aloe vera. J Am Podiatr Med Assoc 79: 559-562.

Dimmeler S, Zeiher AM (1999) Nitric oxide — an endothelial cell survival factor. Cell Death Differ 10: 964-968.

Dong ZB, Li SP, Hong M, Zhu Q (2005) Hypothesis of potential active components in Angelica sinensis by using biomembrane extraction and high performance liquid chromatography. I Pharm Biomed Anal 38: 664-669.

Dulak J (2005) Nutraceuticals as anti-angiogenic agents: Hopes and reality. I Physiol Pharmacol 56: 51-67.

Eccleston C, Baoru Y, Tahvonen R, Kallio H, Rimbach GH, Minihane AM (2002) Effects of an antioxidant rich juice (sea buckthorn) on risk factors for coronary heart disease in humans. J Nutr Biochem 13: 346-354.
Eliceiri BP, Cheresh DA (1999) The role of alphav integrins during angiogenesis: insights into potential mechanisms of action and clinical development. J Clin Invest 103: 1227-1230.

Falanga V (2005) Wound healing and its impairment in the diabetic foot. Lancet 366: 1736-1743.

Fan TP, Yeh JC, Leung KW, Yue PY, Wong RN (2006) Angiogenesis: from plants to blood vessels. Trends Pharmacol Sci 27: 297-309.

Ferrara N (1999) Molecular and biological properties of vascular endothelial growth factor. J Mol Med 77: 527-543.

Fonder MA, Lazarus GS, Cowan DA, Aronson-Cook B, Kohli AR, Mamelak AJ (2008) Treating the chronic wound: A practical approach to the care of nonhealing wounds and wound care dressings. J Am Acad Dermatol 58: 185-206.

Fukuda S, Kaga S, Zhan L, Bagchi D, Das DK, Bertelli A, Maulik N (2006) Resveratrol ameliorates myocardial damage by inducing vascular endothelial growth factor-angiogenesis and tyrosine kinase receptor Flk-1. Cell Biochem Biophys 44: 43-49.

Furukawa T, Bai CX, Kaihara A, Ozaki E, Kawano T, Nakaya Y, Awais M, Sato M, Umezawa Y, Kurokawa J (2006) Ginsenoside Re, a main phytosterol of Panax ginseng, activates cardiac potassium channels via a nongenomic pathway of sex hormones. Mol Pharmacol 70: 1916-1924.

Ganju L, Padwad Y, Singh R, Karan D, Chanda S, Chopra MK, Bhatnagar P, Kashyap R, Sawhney RC (2005) Anti-inflammatory activity of Seabuckthorn (Hippophae rhamnoides) leaves. Int Immunopharmacol 12: $1675-1684$.

Giordano FJ, Johnson RS (2001) Angiogenesis: the role of the microenvironment in flipping the switch. Curr Opin Genet Dev 11: 35-40.

Goldman M (1996) Cancer risk of low-level exposure. Science 271: 1821-1822.

Gupta A, Upadhyay NK, Sawhney RC, Kumar R (2008) A poly-herbal formulation accelerates normal and impaired diabetic wound healing. Wound Rep Regen 16:784-790.

Gurtner GC, Werner S, Barrandon Y, Longaker MT (2008) Wound repair and regeneration. Nature 453: 314-321.

Hattori R, Otani H, Maulik N, Das DK (2002) Pharmacological preconditioning with resveratrol: role of nitric oxide. Am J Physiol Heart Circ Physiol 282: H1988-1995.

Hoeben A, Landuyt B, Highley MS, Wildiers H, Van Oosterom AT, De Bruijn EA (2004) Vascular endothelial growth factor and angiogenesis. Pharmacol Rev 56: 549-580.

Hong SJ, Wan JB, Zhang Y, Hu G, Lin HC, Seto SW, Kwan YW, Lin ZX, Wang YT, Lee SM (2009) Angiogenic effect of saponin extract from Panax notoginseng on HUVECs in vitro and zebrafish in vivo. Phytother Res 23: 677-686.

Hoo RL, Wong JY, Qiao C, Xu A, Xu H, Lam KS (2010) The effective fraction isolated from Radix Astragali alleviates glucose intolerance, insulin resistance and hypertriglyceridemia in $\mathrm{db} / \mathrm{db}$ diabetic mice through its anti-inflammatory activity. Nutr Metab 7: 67.

Huang YC, Chen CT, Chen SC, Lai PH, Liang HC, Chang Y, Yu LC, Sung HW (2005) A natural compound (ginsenoside Re) isolated from Panax ginseng as a novel angiogenic agent for tissue regeneration. Pharm Res 22: 636-646.

Jagetia GC, Rajanikant GK (2004) Role of curcumin, a naturally occurring phenolic compound of turmeric in accelerating the repair of excision wound, in mice whole-body exposed to various doses of gamma-radiation, J Surg Res 120: 127-138.

Jeon J, Lee J, Kim C, An Y, Choi C (2010) Aqueous extract of the medicinal plant Patrinia villosa Juss. Induces angiogenesis via activation of focal adhesion kinase. Microvasc Res 80: 303-309.

Jettanacheawchankit S, Sasithanasate S, Sangvanich P, Banlunara W, Thunyakitpisal P (2009) Acemannan stimulates gingival fibroblast proliferation; expressions of keratinocyte growth factor-1, vascular endothelial growth factor, and type I collagen; and wound healing. $J$ Pharmacol Sci 109: 525-531.

Kaga S, Zhan L, Matsumoto M, Maulik N (2005) Resveratrol enhances neovascularization in the infarcted rat myocardium through the induction of thioredoxin-1, heme oxygenase-1 and vascular endothelial growth factor. J Mol Cell Cardiol 39: 813-822.

Khanna S, Roy S, Bagchi D, Bagchi M, Sen CK (2001) Upregulation of oxidant-induced VEGF expression in cultured keratinocytes by a grape seed proanthocyanidin extract. Free Radic Biol Med 31: 38-42.

Kim KW (2006) Angiogenic effect. In New perspectives on Aloe, Park YI, Lee SK eds, pp 82-94. Springer, US.

Kim YG, Sumiyoshi M, Sakanaka M, Kimura Y (2009) Effects of ginseng saponins isolated from red ginseng on ultraviolet B-induced skin aging in hairless mice. Eur I Pharmacol 602: 148-156.

Kim YM, Namkoong S, Yun YG, Hong HD, Lee YC, Ha KS, Lee H, Kwon HJ, Kwon YG, Kim YM (2007) Water extract of Korean red ginseng stimulates angiogenesis by activating the PI3K/Aktdependent ERK1/2 and eNOS pathways in human umbilical vein endothelial cells. Biol Pharm Bull 30: 1674-1679.

Kostelac D, Rechkemmer G, Briviba K (2003) Phytoestrogens modulate binding response of estrogen receptors alpha and beta to the estrogen response element. J Agric Food Chem 51: 7632-7635. 
Krump-Konvalinkova V, Yasuda S, Rubic T, Makarova N, Mages J, Erl W, Vosseler C, Kirkpatrick CJ, Tigyi G, Siess W (2005) Stable knock-down of the sphingosine 1-phosphate receptor S1P1 influences multiple functions of human endothelial cells. Arterioscler Thromb Vasc Biol 25: 546-552.

Kuida K, Boucher DM (2004) Functions of MAP kinases: insights from gene-targeting studies. J Biochem 135: 653-656.

Kumar B, Vijayakumar M, Govindarajan R, Pushpangadan P (2007) Ethnopharmacological approaches to wound healing-exploring medicinal plants of India. J Ethnopharmacol 114: 103-113.

Lam HW, Lin HC, Lao SC, Gao JL, Hong SJ, Leong CW, Yue PY, Kwan YW, Leung AY, Wang YT, Lee SM (2008) The angiogenic effects of Angelica sinensis extract on HUVEC in vitro and Zebrafish in vivo. J Cell Biochem 103:195-211.

Lao SC, Li SP, Kan KKW, Li P, Wan JB, Wang Y'T, Dong TTX, Tsim KWK (2004) Identification and quantification of 13 components in Angelica sinensis (Danggui) by gas chromatography-mass spectrometry coupled with pressurized liquid extraction. Anal Chim Acta 526: $131-137$.

Lau TW, Chan YW, Lau CP, Lau KM, Lau CB, Fung KP, Leung PC, Ho YY (2009) Radix Astragali and Radix Rehmanniae, the principal components of two antidiabetic foot ulcer herbal formulae, elicit viability-promoting effects on primary fibroblasts cultured from diabetic foot ulcer tissues. Phytother Res 23: 809-815.

Lay IS, Chiu JH, Shiao MS, Lui WY, Wu CW (2003) Crude extract of Salvia miltiorrhiza and salvianolic acid $\mathrm{B}$ enhance in vitro angiogenesis in murine SVR endothelial cell line. Planta Med 69: 26-32.

Lay IS, Hsieh CC, Chiu JH, Shiao MS, Lui WY, Wu CW (2003) Salvianolic acid $\mathrm{B}$ enhances in vitro angiogenesis and improves skin flap survival in Sprague-Dawley rats. J Surg Res 115: 279-285.

Lee MJ, Lee OH, Yoon SH, Lee SK, Chung MH, Park YI, Sung CK, Choi JS, Kim KW (1998) In vitro angiogenic activity of Aloe vera gel on calf pulmonary artery endothelial (CAPE) cells. Arch Pharm Res 21: 260-265.

Lee MJ, Yoon SH, Lee SK, Chung MH, Park YI, Sung CK, Choi JS, Kim KW (1995) In vivo angiogenic activity of dichloromethane extracts of Aloe vera gel. Arch Pharm Res 18: 332-335.

Lee TH, Lee GW, Kim CW, Bang MH, Baek NI, Kim SH, Chung DK, Kim I (2010) Stewartia koreana extract stimulates proliferation and migration of human endothelial cells and induces neovasculization in vivo. Phytother Res 24: 20-25.

Lee YJ, Chung E, Lee KY, Lee YH, Huh B, Lee SK (1997) Ginsenoside-Rg1, one of the major active molecules from Panax ginseng, is a functional ligand of glucocorticoid receptor. Mol Cell Endocrinol 133: 135-140.

Leung KW, Cheng YK, Mak NK, Chan KK, Fan TP, Wong RN (2006) Signaling pathway of ginsenoside-Rg1 leading to nitric oxide production in endothelial cells. FEBS Lett 580: 3211-3216.

Li TS, Beveridge TH (2003) In Sea buckthorn (Hippophae rhamnoides L.): production and utilization. NRC Research Press, Ottawa.

Li SL, Li P, Sheng LH, Li RY, Qi LW, Zhang LY (2006) Live cell extraction and HPLC-MS analysis for predicting bioactive components of traditional Chinese medicines. I Pharm Biomed Anal 41: 576-581.

Li TSC, Oomah BD, Smith A (1999) Sea buckthorn products: manufacture and composition. J Agri. Food Chem 47: 3480-3488.

Liang HC, Chen CT, Chang Y, Huang YC, Chen SC, Sung HW (2005) Loading of a novel angiogenic agent, ginsenoside $\mathrm{Rg} 1$ in an acellular biological tissue for tissue regeneration. Tissue Eng 11: 835-846.

Lin YG, Kunnumakkara AB, Nair A, Merritt WM, Han LY, ArmaizPena GN, Kamat AA, Spannuth WA, Gershenson DM, Lutgendorf SK, Aggarwal BB, Sood AK (2007) Curcumin inhibits tumor growth and angiogenesis in ovarian carcinoma by targeting the nuclear factor-kappaB pathway. Clin Cancer Res 13: 3423-3430.

Lu J, Yao Q, Chen C (2009) Ginseng compounds: an update on their molecular mechanisms and medical applications. Curr V asc Pharmacol 7: 293-302.

Lü J, Ma Z, Yang J, Huang J, Wang S, Wang S (2004) Ginsenoside Rg1-induced alterations in gene expression in TNF- $\alpha$ stimulated endothelial cells. Chinese Medical Journal 117: 871-877.

Ma XQ, Shi Q, Duan JA, Dong TT, Tsim KW (2002) Chemical analysis of Radix Astragali (Huangqi) in China: a comparison with its adulterants and seasonal variations. J Agric Food Chem 50: 48614866.

Ma ZC, Gao Y, Wang J, Zhang XM, Wang SQ (2006) Proteomic analysis effects of ginsenoside Rg1 on human umbilical vein endothelial cells stimulated by tumor necrosis factor- $\alpha$. Life Sci 79: 175-181.

Maenthaisong R., Chaiyakunapruk N., Niruntraporn S., Kongakaew Ch (2007) The efficacy of Aloe vera used for burn wound healing: A systematic review. Burns 33: 713- 718 .

Matsumoto T, Claesson-Welsh L (2001) VEGF receptor signal transduction. Sci STKE 112: re21.

Meng H, Guo J, Sun JY, Pei JM, Wang YM, Zhu MZ, Huang C (2008) Angiogenic effects of the extracts from Chinese herbs: Angelica and Chuanxiong. Am J Chin Med 36: 541-554.

Moon EJ, Lee YM, Lee OH, Lee MJ, Lee SK, Chung MH, Park YI, Sung CK, Choi JS, Kim KW (1999) A novel angiogenic factor de- rived from Aloe vera gel: beta-sitosterol, a plant sterol. Angiogenesis 3: $117-123$.

Morisaki N, Watanabe S, Tezuka M, Zenibayashi M, Shiina R, Koyama N, Kanzaki T, Saito Y (1995) Mechanism of angiogenic effects of saponin from Ginseng Radix rubra in human umbilical vein endothelial cells. Br J Pharmacol 115: 1188-1193.

Mukherjee S, Dudley JI, Das DK (2010) Dose-dependency of resveratrol in providing health benefits. Dose Response 8: 478-500.

Ososki AL, Kennelly EJ (2003) Phytoestrogens: a review of the present state of research. Phytother Res 17: 845-869.

Papanas N, Maltezos E (2007) Growth factors in the treatment of diabetic foot ulcers: new technologies, any promises? Int J Low Extrem Wounds 6: 37-53.

Park JE, Keller GA, Ferrara N (1993) The vascular endothelial growth factor (VEGF) isoforms: differential deposition into the subepithelial extracellular matrix and bioactivity of extracellular matrix-bound VEGF. Mol Biol Cell 4: 1317-1326.

Parks AH (1999) Equine foot wounds: general principles of healing and treatment. Proc Am Assoc Equine Pract 45: 180-187.

Patel GK, Wilson CH, Harding KG, Finlay AY, Bowden PE (2006) Numerous keratinocyte subtypes involved in wound re-epithelialization. I Invest Dermatol 126: 497-502.

Pettet GJ, Chaplain MAJ, McElwain DLS, Byrne HM (1996) On the role of angiogenesis in wound healing. Proc Biol Sci 263: 1487-1493

Robinson MJ, Cobb MH (1997) Mitogen-activated protein kinase pathways. Curr Opin Cell Biol 9: 180-6.

Robson MC, Steed DL, Franz MG (2001) Wound healing: biologic features and approaches to maximize healing trajectories. Curr Probl Surg 38: 72-140.

Schultz GS (2007) Molecular regulation of wound healing. In Acute and Chronic Wounds: Current Management Concepts, 3rd edn, Bryant RA, Nix DP eds, pp 82-99. Mosby Inc., St. Louis, MO.

Sengupta S, Toh S-A, Sellers LA, Skepper JN, Koolwijk P, Leung HW, Yeung H-W, Wong RNS, Sasisekharan R, Fan T-PD (2004) Modulating angiogenesis: the Yin and the Yang in ginseng. Circulation 110: 1219-1225.

Sharma RA, McLelland HR, Hill KA, Ireson CR, Euden SA, Manson MM, Pirmohamed M, Marnett LJ, Gescher AJ, Steward WP (2001) Pharmacodynamic and pharmacokinetic study of oral curcuma extract in patients with colorectal cancer. Clin Cancer Res 7: 1894-1900.

Simoncini T, Hafezi-Moghadam A, Brazil DP, Ley K, Chin WW, Liao JK (2000) Interaction of oestrogen receptor with the regulatory subunit of phosphatidylinositol-3-OH kinase. Nature 407: 538-541.

Somanath PR, Razorenova OV, Chen J, Byzova TV (2006) Akt1 in endothelial cell and angiogenesis. Cell Cycle 5: 512-518.

Stetler-Stevenson WG (2008) The tumor microenvironment: regulation by MMP-independent effects of tissue inhibitor of metalloproteinases-2. Cancer Metastasis Rev 27: 57-66.

Strodtbeck F (2001) Physiology of Wound Healing. New Inf Nurs Rev 1: 43-52.

Tanaka K, Abe M, Sato Y (1999) Roles of extracellular signal-regulated kinase $1 / 2$ and p38 mitogen-activated protein kinase in the signal transduction of basic fibroblast growth factor in endothelial cells during angiogenesis. Jpn J Cancer Res 90: 647-654.

Tang JY, Li S, Li ZH, Zhang ZJ, Hu G, Cheang LC, Alex D, Hoi MP, Kwan YW, Chan SW, Leung GP, Lee SM (2010) Calycosin promotes angiogenesis involving estrogen receptor and mitogenactivated protein kinase (MAPK) signaling pathway in zebrafish and HUVEC. PLoS One 5: e11822.

Tang LL, Sheng JF, Xu CH, Liu KZ (2009) Clinical and experimental effectiveness of Astragali compound in the treatment of chronic viral hepatitis B. J Int Med Res 37: 662-667.

Tombran-Tink J, Barnstable CJ (2006) Preface In Ocular angiogenesis: diseases, mechanisms, and therapeutics. Tombran-Tink J, Barnstable CJ ed, pp V-VII. Humana Press, New Jersey.

Tsuzuki Y, Fukumura D, Oosthuyse B, Koike C, Carmeliet P, Jain RK (2000) Vascular endothelial growth factor (VEGF) modulation by targeting hypoxia-inducible factor- 1 alpha $\rightarrow$ hypoxia response element $\rightarrow$ VEGF cascade differentially regulates vascular response and growth rate in tumors. Cancer Res 60: 6248-6252.

Tyrone JW, Marcus JR, Bonomo SR, Mogford JE, Xia Y, Mustoe TA (2000) Transforming growth factor b3 promotes fascial wound healing in a new animal model. Arch Surg 135: 1154-1159.

Upadhyay NK, Kumar R, Mandotra SK, Meena RN, Siddiqui MS, Sawhney RC, Gupta A (2009) Safety and healing efficacy of sea buckthorn (Hippophae rhamnoides $L$.) seed oil on burn wounds in rats. Food Chem Toxicol 47: 1146-1153.

Upadhyay NK, Kumar R, Siddiqui MS, Gupta A (2009) Mechanism of wound-healing activity of Hippophae rhamnoides L. leaf extract in experimental burns. Evid Based Complement Alternat Med 2011: 659705659804.

Upadhyay NK, Yogendra Kumar MS, Gupta A (2010) Antioxidant, cytoprotective and antibacterial effects of Sea buckthorn (Hippophae rhamnoides L.) leaves. Food and Chem Toxicol 48: 3443-3448. 
Urbich C, Dimmeler S (2005) Risk factors for coronary artery disease, circulating endothelial progenitor cells, and the role of HMG-CoA reductase inhibitors. Kidney Int 67: 1672-1676.

World Health Organization (WHO) (1999) WHO Monographs on Selected Medicinal Plants. Vol. 1, pp 50-58. WHO Publications, Geneva.

Velnar T, Bailey T, Smorkolj V (2009) The wound healing process: an overview of the cellular and molecular mechanisms. J Int Med Res 37: 1528-1542

Xiao PG, Liu CX (1999) Immunostimulants in traditional Chinese medicine. In Immunomodulatory Agents from Plants, Wagner $\mathrm{H}$ ed, pp 325-356. Basel: Birkhaser Verlag.

Xin X, Liu J, Li X, Zhong J, Wei D (2006) Extraction of 20(S)-ginsenoside Rg2 from cultured Panax notoginseng cells in vitro stimulates human umbilical cord vein endothelial cell proliferation. Am J Ther 13: 205-210.

Xu XL, Ji H, Gu SY, Shao Q, Huang QJ, Cheng YP (2008) Cardioprotective effects of Astragali Radix against isoproterenol-induced myocardial injury in rats and its possible mechanism. Phytother Res 22: 389-394.

Yang B, Karlsson RM, Oksman PH, Kallio HP (2001) Phytosterols in sea buckthorn (Hippophä̈ rhamnoides L.) berries: identification and effects of different origins and harvesting times. I Agric Food Chem 49: 5620-5629.

Ye YN, Koo MWL, Li Y, Matsui H, Cho CH (2001) Angelica sinensis modulates migration and proliferation of gastric epithelial cells. Life Sciences 68: 961-968.

Ye YN, Liu ESL, Shin VY, Koo MWL, Li Y, Wei EQ, Matsui H, Cho $\mathrm{CH}$ (2001) A mechanistic study of proliferation induced by Angelica sinensis in a normal gastric epithelial cell line. Biochem Pharmacol 61: 1439-1448.

Ye YN, So HL, Liu ESL, Shin VY, Cho CH (2003) Effect of polysaccharides from Angelica sinensis on gastric ulcer healing. Life Sciences 72: 925-932.
Yeh JC, Cindrova-Davies T, Belleri M, Morbidelli L, Miller N, Cho CW, Chan K, Wang YT, Luo GA, Ziche M, Presta M, CharnockJones DS, Fan TP (2011) The natural compound n-butylidenephthalide derived from the volatile oil of Radix Angelica sinensis inhibits angiogenesis in vitro and in vivo. Angiogenesis 14: 187-197.

Yue PY, Mak NK, Cheng YK, Leung KW, Ng TB, Fan DT, Yeung HW, Wong RN (2007) Pharmacogenomics and the Yin/Yang actions of ginseng: anti-tumor, angiomodulating and steroid-like activities of ginsenosides. Chin Med 2: 6.

Yue PY, Wong DY, Ha WY, Fung MC, Mak NK, Yeung HW, Leung HW, Chan K, Liu L, Fan TP, Wong RN (2005) Elucidation of the mechanisms underlying the angiogenic effects of ginsenoside $\operatorname{Rg}(1)$ in vivo and in vitro. Angiogenesis 8: 205-216.

Wu D, Lei Y, Tong Y, Tang F, Qian Y, Zhou Y (2010) Angiogenesis of the frozen-thawed human fetal ovarian tissue at the early stage after xenotransplantation and the positive effect of Salviae miltiorrbizae. Anat Rec (Hoboken) 293: 2154-2162.

Zhang Y, Hu G, Lin HC, Hong SJ, Deng YH, Tang JY, Seto SW, Kwan YW, Waye MM, Wang YT, Lee SM (2009) Radix Astragali extract promotes angiogenesis involving vascular endothelial growth factor receptor-related phosphatidylinositol 3-kinase/Akt-dependent pathway in human endothelial cells. Phytother Res 23: 1205-1213.

Zhao Z, Wang W, Wang F, Zhao K, Han Y, Xu W, Tang L (2009) Effects of Astragaloside IV on heart failure in rats. Chin Med 4: 6.

Zheng KY, Choi RC, Cheung AW, Guo AJ, Bi CW, Zhu KY, Fu Q, Du Y, Zhang WL, Zhan JY, Duan R, Lau DT, Dong TT, Tsim KW (2011) Flavonoids from Radix Astragali induce the expression of erythropoietin in cultured cells: a signaling mediated via the accumulation of hypoxia-inducible factor-1 $\alpha$. J Agric Food Chem 59: 1697-1704.

Zu Y, Li C, Fu Y, Zhao C (2006) Simultaneous determination of catechin, rutin, quercetin kaempferol and isorhamnetin in the extract of Sea buckthorn (Hippophae rhamnoides L.) leaves by RP-HPLC with DAD. J Pharm Biomed Anal 41: 714-719. 